\title{
Agnieszka Bień-Kacała
}

Uniwersytet Mikołaja Kopernika w Toruniu

\section{RECENZJA: KAMILA DOKTÓR-BINDAS, WPEYW PRAWA UNII EUROPEJSKIEJ NA SYSTEM ŹRÓDEŁ PRAWA REPUBLIKI WŁOSKIEJ, WYDAWNICTWO SEJMOWE, WARSZAWA 2013, SS.294.}

DOI: http://dx.doi.org/10.12775/TSP-W.2014.014

Recenzowana pozycja jest niezwykle cenną monografią na naukowym rynku wydawniczym w Polsce. Takie zdanie w odniesieniu do publikacji Wydawnictwa Sejmowego jest niezmienną regułą. Renomę wydawcy potwierdza także książka K. Doktór-Bindas dotycząca wpływu prawa Unii Europejskiej na system źródeł prawa Republiki Włoskiej.

Na samym początku należy stwierdzić i jednoznacznie przesądzić, że Autorka zajęła się tematyką niezwykle ważną. Uczestnictwo w Unii Europejskiej jest bowiem kwestią dostrzegalną nie tylko w wymiarze społecznym i gospodarczym. Oddziałuje także na porządek prawny państwa członkowskiego i również, co wykazała Pani Kamila Doktór-Bindas, na jego system źródeł prawa. Recenzowana pozycja stanowi całościowe ujęcie tej ostatniej materii. Zasługuje to tym bardziej na podkreślenie, że dotyczy Republiki Włoskiej. System włoski był już wielokrotnie badany przez wybitnych znawców tego prawa ${ }^{1}$, niemniej jednak rzadko pod ką-

${ }^{1}$ Por. np. Z. Witкowsкi, Ustrój konstytucyjny współczesnych Włoch w aktualnej fazie jego przemian 1989-2004, Toruń 2004; tenże, Postępowanie ustawodawcze we Włoszech, [w:] Postępowanie ustawodawcze, E. Zwierzchowski (red.), Warszawa 1993; Z. Wiткоwsкi, K. WiткоwsкA-Chrzczonowicz, Konstytucje narodowe a zasada prymatu prawa wspólnotowego na tle orzecznictwa Sadu Konstytucyjnego Republiki Wtoskiej i Trybunału Konstytucyjnego RP, [w:] Tworzenie prawa w Polsce $i$ we Włoszech (wybrane problemy), J. Wawrzyniak, Warszawa 2008; A. KustrA, Ewolucja wykładni art. 11 Konstytucji Włoch z 1947 r. w orzecznictwie Sądu Konstytucyjnego, „Europejski Przegląd Sądowy” 9/2008. 
tem wyłącznie całościowego ujęcia źródeł prawa. Pamiętajmy także, że podobnej pozycji nie ma w odniesieniu do systemu źródeł prawa polskiego. Badania w tym temacie, rzecz jasna odnajdziemy w literaturze ${ }^{2}$. Brakuje natomiast całościowego opracowania na miarę tego, które zaprezentowała Pani Kamila Doktór-Bindas.

Rozważania zamieszczone w recenzowanej pracy pozostają na wysokim poziomie, jeśli chodzi o ich walor merytoryczny oraz praktyczne znaczenie. Wykracza ono dalece poza system zakreślony tytułem, jeśli chodzi o walor teoretyczny. Recenzowanej książki nie sposób ograniczyć tylko do wartości poznawczej i materiału komparatystycznego. Stanowi ona bowiem istotny wkład teoretyczny do relacji między systemem prawa krajowego a systemem prawa unijnego. Przy czym nie chodzi tu o relacje merytoryczne (materialne) ale zwłaszcza o relacje między systemami prawnymi w warunkach ich multicentryczności. Porządki prawne oparte o własne reguły kształtujące trudno jest pogodzić, w sytuacji, gdy jeden i drugi przewiduje własną supremację (Kelsenowska reguła konstytucji jako prawa o najwyższej mocy prawnej oraz integracyjna reguła pierwszeństwa prawa unijnego). Relacje między wskazanymi ośrodkami zachodzą na kilku płaszczyznach, które zostały oddzielnie omówione w pracy. Będzie to przede wszystkim interpretacja norm prawnych, ich stanowienie oraz stosowanie. Autorka ukazuje bardzo wyraźnie drogę, którą przyjęła Republika Włoska działająca zwłaszcza przez Sąd Konstytucyjny. Polega ona obecnie na przyjaznym traktowaniu prawa europejskiego we włoskim porządku prawnym. Punkt wyjściowy był jednak zasadniczo odmienny. W układzie systemowym można zadać pytanie, czy porządki te są wobec siebie równorzędne czy też usytuowane hierarchicznie. Ma to znaczenie przy ustalaniu właściwej normy prawnej w warunkach nierozwiązywalnego konfliktu regulacji unijnej i krajowej.

Wskazany problem obecny jest właściwie w każdym państwie członkowskim Unii Europejskiej. Boryka się z nim także Polska. Tym większe znaczenie przypisać wypada recenzowanej pozycji. Stanowi ona doskonały materiał do badań porównawczych. Przy czym podkreślić trzeba, że rozważania zawarte w pracy nie stanowią wyłącznie odtwórczej aktywności. Pani Kamila Doktór-Bindas opatrzyła je własnym komentarzem i spostrzeżeniami. Książka osadzona została wyłącznie we Włoskich realiach ustrojowych, materiale normatywnym, doktrynalnym i orzeczniczym. Nie znajdziemy w niej w zasadzie odniesień do innych porządków prawnych państw członkowskich Unii Europejskiej, w tym Polski. Brak analizy porównawczej tak wskazanej nie może być jednak zarzutem wobec

2 Por. np. B. Skwara, Rozporzqdzenie jako akt wykonawczy do ustawy w polskim prawie konstytucyjnym, Warszawa 2010; A.BIEŃ-KaCAŁA, Źródła prawa wewnętrznego w Konstytucji Rzeczypospolitej Polskiej z 1997 roku, Toruń 2013. 
pracy i jaj Autorki. Badania komparatystyczne nie były założeniem postawionym przez K. Doktór-Bindas. Słusznie więc w pracy odnajdziemy wyłącznie włoski wątek badawczy. Niemniej jednak, co zostało już wskazane, takie ujęcie problemu stanowi ważny materiał porównawczy dla dalszych szczegółowych badań. To samo w sobie świadczy o istotnym znaczeniu recenzowanej książki.

Zaznaczyć przy tym wypada, że system źródeł prawa, zwłaszcza powszechnie obowiązującego, w świetle Konstytucji RP z 1997 r. nie jest tak skomplikowany, jak ten, który został przewidziany przez ustrojodawcę włoskiego. Polska ustawa zasadnicza natomiast, właściwie na zasadzie wyjątku wśród regulacji tego typu, określa system źródeł prawa w odrębnym rozdziale traktując go całościowo. Oznacza to, że kwestia osadzenia aktów supranacjonalnych w systemie źródeł prawa została zauważona przez ustrojodawcę i, przynajmniej częściowo, rozwiązana. Chodzi zwłaszcza o wyraźne wskazanie pewnych reguł kolizyjnych istotnych przy rozstrzyganiu konfliktów w zakresie stosowania prawa. Rozwiązania takiego nie przewiduje Konstytucja Republiki Włoskiej z 1947 r. Jest to konstatacja dość oczywista w związku z momentem historycznym tworzenia konstytucji obu państw oraz ich członkostwa w Unii Europejskiej (wcześniej we Wspólnotach).

Wykorzystując książkę Pani Kamili Doktór-Bindas w celach prawnoporównawczych trzeba także zauważyć pewne, wskazane na zasadzie przykładu, różnice w systemach źródeł prawa obu państw zaliczanych do kategorii unitarnych. Ma to znaczenie w kontekście umiejscowienia w systemie aktów stanowionych przez organy samorządu terytorialnego. Akty prawa miejscowego w Polsce mają charakter wyłącznie wykonawczy względem ustaw, nawet przy ogólnym powiązaniu z ustawami samorządowymi (chodzi zwłaszcza o statuty jednostek samorządu terytorialnego oraz przepisy porządkowe). W Republice Włoskiej mamy do czynienie $\mathrm{z}$ autonomią regionalną, co rzutuje na miejsce aktów autonomicznych w systemie. Inną różnicą jest z kolei możliwość derogacji ustawy w trybie referendum, które zaliczane do źródeł prawa. Ma to oczywiście swoiste znaczenie w kontekście unijnym. Z punktu widzenia głównego wątku pracy istotne są akty delegowane. Chodzi przede wszystkim o akty wydawane na podstawie ustaw upoważniających. Zwłaszcza ustawy wspólnotowej, która upoważnia rząd w bardzo szeroki sposób, w tym do zmian w obowiązujących przepisach implementacyjnych. W ramach polskiej dyskusji na temat usprawnienia procedury implementacji prawa unijnego postuluje się wprowadzenie do systemu źródeł prawa także rozporządzeń z mocą ustawy ${ }^{3}$. Akty te miałyby przyśpieszyć wdro-

${ }^{3}$ Por. R. Piotrowski, O potrzebie rozporzadzeń z mocq ustawy w polskim systemie tworzenia prawa, [w:] Zasady naczelne w Konstytucji RP z 2 kwietnia 1997 roku, A. Bałaban (red.), Szczecin 2011. 
żenie koniecznych rozwiązań europejskich. Zwrócić tu jednak trzeba uwagę na słuszną konstatację Autorki o powszechnym użyciu tego typu instrumentów rządowych, co przekracza przyjęte ramy konstytucyjne w zakresie ich wyjątkowości. Ujawniają się tym samym wątpliwości w zakresie zasadności stosowania tego instrumentu implementacyjnego.

Z punktu widzenie systemu źródeł prawa istotne są pewne elementy do analizy o charakterze komparatystycznym. Nie wszystkie jednak kwestie można odnaleźć w pracy. Chodzi zwłaszcza o strukturę włoskiego systemu źródeł prawa wyróżnianą w związku z możliwością regulacji sytuacji prawnej jednostki (prawo powszechnie i wewnętrznie obowiązujące), zamkniętość systemu oraz znaczenie prawa unijnego dla aktów prawa stanowionych przez organy administracji (przy czym nie chodzi wyłącznie o rozporządzenia). Odpowiedź na te kwestie jest istotna z uwagi na system źródeł prawa przyjęty w Konstytucji RP z 1997 r. Obok elementów analizowanych w książce, także wskazane kategorie oddałyby w miarę spójną całość relewantnej porównawczo materii.

Książka została logicznie uporządkowana. Rozważania są ściśle podporządkowane tytułowi pracy i ujawnionym we wstępie tezom. Opracowanie składa się z czterech rozdziałów i opatrzone jest poprawnie skonstruowanym wstępem oraz zwięzłym zakończeniem. Ten ostatni zabieg możliwy jest do zastosowania w sytuacji zawarcia w każdym z merytorycznych rozdziałów podsumowania. Tak uczyniła Autorka recenzowanej książki. Pozwoliło to na uwypuklenie istotnych dla wywodu treści.

Pierwszy rozdział pracy poświęcony został systemom źródeł prawa Republiki Włoskiej oraz Unii Europejskiej. Ten pierwszy stanowi istotną wartość w badaniach porównawczych. Jak słusznie zauważa K. Doktór-Bindas system źródeł prawa we Włoszech jest bardzo skomplikowany i nie sposób dokonać szczegółowej analizy na kilkudziesięciu stronach pracy. Stąd też założeniem stało się opisanie źródeł prawa ujętych w dwustopniową strukturę (akty pierwszego i drugiego stopnia) oraz wskazanie miejsca prawa międzynarodowego w krajowym systemie źródeł prawa. Autorka zauważa przy tym, że podstawowe źródło prawa w postaci ustawy stanowionej przez legislatywę doznało obniżenia znaczenia na rzecz aktów o mocy ustawy pochodzących od egzekutywy. Świadczy to o zachwianiu równowagi między wskazanymi organami władzy państwowej. Zjawisko to zachodzi również na linii władzy centralnej i regionalnej, zwłaszcza po reformie konstytucyjnej z roku 2001 r. Zaznacza się silnie działanie reguły, zgodnie z którą ustawa parlamentu nie może wkraczać w konstytucyjnie wskazany zakres regulacji statutu regionalnego. Unijny system źródeł prawa potraktowany został natomiast rekonstrukcyjnie, jako niezbędną dla głównego wywodu, część pracy. Autorka zachowała przy tym właściwe proporcje między niezbędnością wątku a szczegółowością rozważań. 
Drugi rozdział dotyczy relacji między prawem Unii Europejskiej a prawem krajowym Republiki Włoskiej. Podzielony został na dwie części. Pierwsza z nich jest częścią, można rzec, historyczną i obejmuje etapy ewolucji linii orzeczniczej włoskiego Sądu Konstytucyjnego. Druga zaś dotyczy dojrzałej formuły przyjętej przez Sąd Konstytucyjny w odniesieniu do relacji prawa krajowego i prawa unijnego. Pani Kamila Doktór-Bindas wskazuje na swoistą, opartą o dużą dozę sceptycyzmu, drogę integracji dwóch porządków prawnych. Przy czym istotna jest tutaj rola włoskiego Sądu Konstytucyjnego odzwierciedlona w doktrynie controlimiti chroniącej ustawę zasadniczą oraz cały porządek prawny przed naruszeniem podstawowych zasad ładu konstytucyjnego oraz praw człowieka. Doktryna ta ustala pewną przeszkodę w ograniczaniu suwerenności dopuszczonej art. 11 Włoskiej Konstytucji. Zakładany skutek polega na odmowie zastosowania unijnego uregulowania. Uwidacznia się w tym kontekście przyjęcie możliwości derogowania postanowień konstytucyjnych przez regulację unijną. Przy czym nie chodzi tutaj o uchylenie normy konstytucyjnej, lecz właśnie o jej niestosowanie. Zasadniczym sposobem rozwiązywania konfliktów na poziomie konstytucyjnym jest tzw. interpretacja zgodna. Autorka słusznie rejestruje w praktyce sądowokonstytucyjnej łagodzenie dualizmu i dążenie do monizmu systemowego $\mathrm{w}$ relacji prawo krajowe-prawo unijne. O procesie tym świadczyć może uznanie zasadności zwracania się przez SK (przełom nastąpił w 2008 r.) do TSUE. Niemniej jednak monizm nie został wyraźnie uznany przez Sąd Konstytucyjny. W wywodzie zauważalny jest pewien obraz relacji między Europejskim Trybunałem Sprawiedliwości (obecnie TSUE) a Sądem Konstytucyjnym. Odzwierciedla to swoistą grę między podstawowymi dla systemów prawnych zasadami - pierwszeństwem prawa europejskiego a nadrzędnością konstytucji. Ostateczny wynik tej gry w ramach całej Unii Europejskiej doprowadzić może w przyszłości do ustalenie stanu równowagi między porządkami prawnymi. Jaka będzie ta formuła, trudno jednoznacznie przesądzić w dobie kryzysu unijnego.

Kolejny, trzeci rozdział pracy poświęcony został oddziaływaniu systemu prawnego Unii Europejskiej na prawodawstwo włoskie. Autorka omawia w nim dwa poziomy tego wpływu, czyli poziom centralny i regionalny. Chodzi przy tym zwłaszcza o sferę stanowienia prawa w celu implementacyjnym na wskazanych poziomach. W tym miejscu pracy szeroko został omówiony problem kolejnych ustaw wspólnotowych oraz instytucji aktów delegowanych, jako jednej, obok implementacji bezpośredniej i implementacji przy wykorzystaniu aktów podustawowych, z formuł wdrożenie prawa unijnego do krajowego porządku prawnego. Autorka rejestruje także szczególne, pilne metody implementacyjne, rzadko wykorzystywane, które uzasadniane są karami finansowymi nakładanymi w konsekwencji braku lub niewłaściwej implementacji. Przy czym formuła im- 
plementacyjna na podstawie ustawy wspólnotowej została oceniona przez Autorkę jako najlepsze z możliwych rozwiązań w warunkach włoskich. Na poziomie regionalnym Pani K. Doktór-Bindas szeroko omawia historyczne kształtowanie się uprawnień implementacyjnych oraz praktykę w tym zakresie, łącznie z konsekwencjami braku implementacji prawa unijnego przez organy regionalne.

Ostatni rozdział pracy poświęcony został oddziaływaniu systemu prawnego Unii Europejskiej na sądowe stosowanie prawa w Republice Włoskiej. W tym zakresie K. Doktór-Bindas omawia oddziaływanie na stosowanie prawa w ramach sądów włoskich oraz Sądu Konstytucyjnego. Przybliża także instytucję pytań prejudycjalnych, które zasadniczo kształtują sposób oddziaływania systemu prawnego UE na sądowe stosowanie prawa we Włoszech. Formą sądowego stosowania prawa unijnego najczęściej występującą w praktyce jest odwoływanie się do tego porządku prawnego przez sądy powszechnie w codziennej praktyce orzeczniczej. Praktyka ta obejmuje także zwracanie się do TSUE z pytaniem prejudycjalnym. Istotny jest przy tym, wskazywany już, efekt niestosowania jako konsekwencja niezgodności prawa włoskiego z bezpośrednio skutecznym prawem europejskim. Autorka zauważ także słusznie, że fenomen prawa unijnego wyrasta ponad klasyczny schemat dualizmu i monizmu systemów prawnych. Nie jest więc łatwe rozwiązywanie powstających w praktyce konfliktów między normami w nich zawartymi. Innym zagadnieniem poruszonym w tej części pracy jest kategoria wykładni, można rzec przyjaznej, zgodnej z prawem unijnym i jednocześnie z konstytucją. Sytuacja zazębiania się interesujących nas porządków prawnych oraz kompetencji organów orzeczniczych (TSUE i SK) prowadzi także do tzw. podwójnej prejudycjalności w zakresie norm pozbawionych bezpośredniej skuteczności w prawie krajowym.

W końcowej części książki odnajdziemy szczególne problemy związane $\mathrm{z}$ obecnością prawa unijnego we włoskim porządku prawnym w kontekście działalności SK, chodzi zwłaszcza o możliwość i przypadki kontroli konstytucyjności prawa europejskiego oraz możliwość zastosowania referendum abrogacyjnego w kontekście prawa Unii Europejskiej i oceny dopuszczalności wniosku referendalnego. Autorka kończy wywód analizą przypadku zwrócenie się przez Sąd Konstytucyjny do Trybunału Sprawiedliwości z pytaniem prejudycjalnym w 2008 r. Słusznie utożsamia zdarzenie to z początkiem dialogu między wskazanymi organami.

Konstrukcja książki jest więc klarowna, rozważania natomiast dobrze uporządkowane. Autorka zręcznie posługuje się włoską literaturą źródłową oraz imponująco zebranym orzecznictwem sądowym. Zwłaszcza to ostatnie jest umiejętnie wplatane w główny nurt rozwazań z jednej strony. Z drugiej zaś, stanowi ważny kontekst porządkujący wywód Autorki. Ten walor recenzowanej pozycji 
należy podkreślić. Nie byłby on możliwy do osiągnięcia bez doskonałej znajomości języka włoskiego, włoskiej kultury i specyfiki wypowiedzi włoskiej doktryny prawa. Przy czym Autorka uniknęła dość częstych niezręczności językowych powstających na poziomie translacji. Książka napisana została bowiem czystą, piękną polszczyzną. Język pracy jest przy tym jasny, nie ma w nim niepotrzebnych wtrąceń obcojęzycznych zaciemniających wypowiedź Autorki. Postępuje ona z niezbyt często już stosowaną regułą, aby o rzeczach trudnych mówić jasno. Można powiedzieć, że dziś jest to już prawdziwa sztuka. Opanowała ją w wysokim stopniu Pani Kamila Doktór-Bindas i przekuła na spory atut recenzowanego opracowania. 
